\title{
Development and transferability of microsatellite loci for Spondias tuberosa (Anacardiaceae: Sapindales), a species endemic to the Brazilian semi-arid region
}

\author{
V.N. Santos ${ }^{1}$, R.N.C.S. Gama ${ }^{1}$ and C.A.F. Santos ${ }^{2}$ \\ ${ }^{1}$ Programa de Recursos Genéticos Vegetais, Universidade Estadual de Feira \\ de Santana, Novo Horizonte, Feira de Santana, BA, Brasil \\ ${ }^{2}$ Empresa Brasileira de Pesquisa Agropecuária (Embrapa Semiárido), \\ Petrolina, PE, Brasil \\ Corresponding author: C.A.F. Santos \\ E-mail: carlos-fernandes.santos@embrapa.br \\ Genet. Mol. Res. 20 (2): gmr18778 \\ Received December 06, 2020 \\ Accepted May 12, 2021 \\ Published May 31, 2021 \\ DOI http://dx.doi.org/10.4238/gmr18778
}

\begin{abstract}
The umbu tree (Spondias tuberosa) is one of the best known plants of the Brazilian semi-arid region; it has great potential for the fruit market due to excellent consumer acceptance. This tree is not presently cultivated; fruit commercialization is based on extrativism. Consequently, there has been little research on the genetics of this species. Our objective was to develop, evaluate and transfer single sequence repeat (SSR) loci to S. tuberosa to support work on genetic resources and agronomic improvement of this species. SSR loci for the umbu tree were developed from a new enriched genomic library and evaluated by PCR. Fourteen SSR loci developed for $S$. radlkoferi were evaluated for use in $S$. tuberosa, as well as 18 SSR loci previously identified for this species. DNA was extracted from leaf tissue of eight umbu trees available that are part of a germplasm collection located in Petrolina, PE, Brazil. Of the 14 pairs of primers that were tested, six yielded amplicons, and two showed polymorphism in the genotyped samples. All SSR loci of $S$. radlkoferi transferred to the umbu tree species, yielding amplicons; however, only four were polymorphic in this sample. Among the eighteen available species-specific SSR loci, six were polymorphic
\end{abstract}


for these eight trees. Among the 38 loci that we evaluated, 12 were polymorphic in the sample, including two new loci for S. tuberosa. The number of alleles ranged from 2 to 12 , and 10 of them were moderately to highly informative (PIC $>0.50$ ), while nine had heterozygosity greater than 0.50 . The six new SSR loci and the 14 SSR loci transferred from $S$. radlkoferi increase the number of available loci for population studies, germplasm collection and resource management for the development of new umbu tree cultivars.

Key words: Umbu tree; SSR; Plant breeding; SSR

\section{INTRODUCTION}

Spondias (Anacardiacea) is an economically important genus that consists of 17 species, including seven species in the neotropics (Mexico to Brazil) and 10 species in Asia (Aguilar-Bajaras et al., 2014). In Brazil the best-known species are S. tuberosa, S. mombin, S. purpurea, S. dulcis, and S. venulosa. (Balbino et al. 2019). The chromosome number of the genus Spondias is $2 \mathrm{n}=32$; all representatives have similar morphologies (Almeida et al., 2007). Endemic to the Brazilian semiarid region, the umbu fruit tree (S. tuberosa) (Prado and Gibbs, 1993) stands out for its importance, providing a source of income for rural populations in these dry areas, where it can produce fruit because of its resistance to drought, mainly because of specialized root structures (xylopodia), which allow water storage (Lima Filho and Santos, 2009).

According to Zeraik et al. (2016), the fruit of this species is well-appreciated in the Brazilian Northeast, mainly because of its refreshing and acidic flavor; it can be consumed fresh, as a juice, ice cream, sweet, or jam, or as the traditional "umbuzada" (fruit pulp boiled with milk and sugar). Santos et al. (1999) report umbu genotypes with fruit weight greater than $80 \mathrm{~g}$, which is four times larger than the normal average size of this species' fruits. Production of umbu fruit in 2019 was 8544 t, a result of extractivism in eight Brazilian states (IBGE, 2020), since the umbu tree is not cultivated. Breeding work, with the development of new cultivars, is practically inexistent for this species (Lima et al., 2018).

Microsatellites or simple sequence repeat (SSR) markers have been widely applied in genetic studies, including genetic conservation, population genetics, molecular breeding, and paternity testing. This wide range of applications is possible because SSRs are codominant and multi-allelic, are highly reproducible, have good resolution, and can be identified using PCR (Oliveira et al., 2006). Despite their usefulness, SSRs have only been identified for a limited number of economically important species. The number of SSR primers available for plant species is quite variable; often they are insufficient for good genetic characterization. Transferability of SSRs between close species has been evaluated as a means to help overcome this limitation (Varshney et al., 2005).

Nogueira et al. (2015) was able to use 152 of 158 Psidium guajava SSR markers for a group of 16 species of Eugenia. A high percentage (93.3\%) of transferability was also observed for SSR Theobroma grandiflorum loci transferred to T. cacao (Nascimento et al, 2019). Aguilar-Bajaras et al. (2014) developed 14 SSR loci for $S$. radlkoferi and was able to 
transfer some of them to other Spondias spp. Balbino et al (2019) developed 18 SSR loci for the umbu tree, which were also transferred to another three Spondias species. Increasing the number of SSR markers for the umbu tree will facilitate efforts to improve this species, to make better and more efficient use of the genetic variability present in the Embrapa SemiArid tropic germplasm bank (Santos et al., 1999).

The aim of our study was to develop, transfer, and evaluate SSR loci for $S$. tuberosa, for research on genetic resources and improvement of this species.

\section{MATERIAL AND METHODS}

\section{Plant material and DNA extraction}

Young and healthy leaves were collected from accessions BGU 30, 37, 44, 48, 52, 55 and 68 and an additional sample of umbu tree that spontaneously appeared at Embrapa Semiarid. The accessions were from Afranio-PE, Uaua-BA, Anage-BA, America DouradaBA, Parnamirim-PE, Lagoa Grande-PE, and Lontra-MG, respectively, and they were preselected for large fruit size.

DNA extraction was performed based on the CTAB $2 x$ protocol, with some modifications, as described by Santos and Gama (2013). DNA quantification was made through comparative visual analysis of samples on $0.8 \%(\mathrm{w} / \mathrm{v})$ agarose gel, stained with ethidium bromide and standardized at $10 \mathrm{ng} \mu \mathrm{L}^{-1}$ for SSR analysis.

\section{SSR development, transferability, and evaluation of SSR loci}

The genomic DNA was digested by enzymatic hydrolysis, to generate fragments of suitable sizes. A uniform smear from 700 to $1200 \mathrm{bp}$ was observed in the gel. The fragments ligated to the adapters were pre-amplified using the Rsa21 primer. The binding reaction was visualized on a $1 \%$ agarose gel, stained with ethidium bromide, producing a uniform smear from 300 to $1200 \mathrm{bp}$. The reaction was purified using the Quiaquick PCR purification kit. After ligation of the DNA to the adapters, a selection of fragments containing microsatellite sequences was made. Plasmid DNA from each clone was extracted, amplified, purified, and sequenced.

The sequences were analyzed with the Simple Sequence Repeat Identification Tool for the identification of microsatellites. After the microsatellites were identified, the sequences were examined with the Primer 3 plus program (http://www.bioinformatics.nl/cgi-bin/primer3plus/primer3plus.cgi/), to design the primers, excluding in this step the adapter of Rsa21 sequences. The primers were synthesized, and the products amplified by PCR. Eighteen S. tuberosa loci developed by Balbino et al. (2019) and 14 other loci developed for S. radlkoferi by Aguilar-Bajaras (2014) were evaluated for T. tuberosa.

\section{PCR protocol, amplifications, and analysis}

The PCR protocols for all SSR loci were adjusted to a final volume of $10 \mu \mathrm{l}$ : $1 \mathrm{x}$ buffer solution, $2 \mathrm{mM} \mathrm{MgCl} 2,0.22 \mu \mathrm{M}$ of each dNTP, $0.4 \mu \mathrm{M}$ of each primer (forward and reverse), one unit of Taq DNA polymerase and $10 \mathrm{ng}$ of genomic DNA. The amplifications 
were performed in a Biometra thermocycler. The program started with $15 \mathrm{~min}$ at $94^{\circ} \mathrm{C}$, followed by 35 cycles at $94^{\circ} \mathrm{C}$ for $30 \mathrm{~s}, 58$ or $60^{\circ} \mathrm{C}$ for $1 \mathrm{~min}, 72^{\circ} \mathrm{C}$ for $1 \mathrm{~min}$ and a final extension at $72^{\circ} \mathrm{C}$ for $10 \mathrm{~min}$. The PCR products were visualized in a $6 \%$ polyacrylamide gel, stained with silver nitrate, as described by Santos and Gama (2013).

The number of base pairs for each allele was estimated using the reverse mobility method, based on the regression of products of known size based on a $50 \mathrm{bp}$ molecular

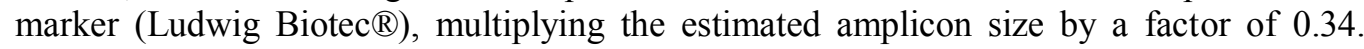
Heterozygosity, allele numbers, and polymorphism information content (PIC), were calculated for each SSR locus, evaluated in the eight individuals of S. tuberosa, using the Cervus 3.0.7 program (Marshall et al., 1998).

\section{RESULTS}

\section{Development of six new SSR loci for $S$. tuberosa}

Among the 14 synthetized primer pairs, six yielded amplicons that were visualized in $6 \%$ polyacrylamide gels stained with silver nitrate (Table 1). Based on the arrangement of the nucleotides within the repeat motifs, the loci were classified as stable; these included five di-nucleotides (SSRU1, SSRU4, SSRU5, SSRU12 and SSRU14) and one tri-nucleotide (SSRU7). Of the six SSR loci, with consistent PCR products, four were monomorphic (SSRU01, SSRU04, SSRU05 and SSRU14) and two were polymorphic (SSRU07 and SSRU12) for the sample of eight umbu tree accessions.

Table 1. Sequences of new SSR primers (Forward - F, reverse - R) developed for Spondias tuberosa, alleles (bp), polymorphic information content (PIC), expected (He) and observed heterozygosity (Ho), repeat motif (MT) and number of alleles (NA). Annealing temperature $=60^{\circ} \mathrm{C}$.

\begin{tabular}{|c|c|c|c|c|c|c|}
\hline Locus & Sequence (5' - 3') & Alleles (bp) & PIC & $\mathrm{He} / \mathrm{Ho}$ & MT & NA \\
\hline SSRU1 & $\begin{array}{l}\text { F:ATATTCGGGGCGGCAAAG } \\
\text { R:TTTTGTGACGACGCATGG }\end{array}$ & 156 & - & - & $(\mathrm{CG}) 3$ & 1 \\
\hline SSRU4 & $\begin{array}{l}\text { F:GTGGACTAACCCTTCGCTCA } \\
\text { R:TTTCTCGATCAACCCCTTTG }\end{array}$ & 163 & - & - & (CT) 3 & 1 \\
\hline SSRU5 & $\begin{array}{l}\text { F:AGGTGGATGGGCTCTCCTAT } \\
\text { R:CCGTTATTTGGCCCTTAGGT }\end{array}$ & 167 & - & - & (TC) 3 & 1 \\
\hline SSRU7 & $\begin{array}{l}\text { F:GTTGTTCAGGGAGGAAAAA } \\
\text { R:TTTCCCGGCTACCAGTATGT }\end{array}$ & $182-187$ & 0.31 & $\begin{array}{l}0.38 / \\
0.32\end{array}$ & $(\mathrm{AAG}) 5$ & 2 \\
\hline SSRU12 & $\begin{array}{l}\text { F:CTGCCTTGGTGTGACTGTGT } \\
\text { R:GCAGAGTGAAAGCCCATGAT }\end{array}$ & $222-264$ & 0.19 & $\begin{array}{l}0.22 / \\
0.25\end{array}$ & $(\mathrm{GT}) 7$ & 2 \\
\hline SSRU14 & $\begin{array}{l}\text { F:ACTTAATCGCCTTGCAGCAC } \\
\text { R:TAAAGGACCCCGATTGACTG }\end{array}$ & 175 & - & - & (GC)Ex & 1 \\
\hline
\end{tabular}

The allele sizes ranged from 156 to 264 bp among the six new S. tuberosa SSR loci (Table 1). The polymorphic information content (PIC) values were 0.31 and 0.19 , the expected heterozygosity values were 0.38 and 0.22 and the observed heterozygosity values were 0.32 and 0.25 , respectively for the SSRU7 and SSRU12 loci (Table 1).

\section{Transferability of SSR loci from Spondias radlkoferi to $S$. tuberosa}

All 14 SSR loci of $S$. radlkoferi evaluated in the eight individuals of $S$. tuberosa produced amplicons in $6 \%$ polyacrylamide gels, demonstrating $100 \%$ transferability. 
However, of the 14 loci of $S$. radlkoferi, only four were polymorphic in the S. tuberosa sample (Table 2). The number of alleles obtained per locus in $S$. tuberosa ranged from three to six, with SPO4 and SPO14 showing the highest allelic diversity, with six and five alleles, respectively; the lowest number was observed for SPO8 and SPO18, which showed only three alleles. (Table 2).

Table 2. Sequences of SSR primers (Forward - F, reverse - R) transferred from Spondias radlkoferi to $S$. tuberosa, alleles (bp), polymorphic information content (PIC), expected (He) and observed heterozygosity (Ho), annealing temperature (Ta), repetition motif (MT) and number of alleles (NA).

\begin{tabular}{|c|c|c|c|c|c|c|}
\hline Locus & Sequence (5' - 3') & Alleles (bp) & PIC & $\mathrm{He} / \mathrm{Ho}$ & $\mathrm{T}_{\mathrm{a}}\left({ }^{\circ} \mathrm{C}\right)$ & NA \\
\hline SSRO4 & $\begin{array}{l}\text { F:CGCTAGTTGTCATTCGCGG } \\
\text { R:GCTTAACCTCTGGAAAGTCGC }\end{array}$ & $186-236$ & 0.74 & $0.83 / 0.73$ & 62 & 6 \\
\hline SSRO8 & $\begin{array}{l}\text { F:GCAGCAGCCATTTGTGAAC } \\
\text { R:CACGTGTTCCCAGTTATGATTTG }\end{array}$ & $172-180$ & 0.43 & $0.51 / 0.63$ & 60 & 3 \\
\hline SSRO14 & $\begin{array}{l}\text { F:ACACCAACGTTTGCGGAG } \\
\text { R:TCTAGGTAGACAGCGACAAATC }\end{array}$ & $218-240$ & 0.64 & $0.74 / 0.88$ & 62 & 5 \\
\hline SSRO18 & $\begin{array}{l}\text { F:TCTATTTGCGTCCAGGTATTTC } \\
\text { R:GAATGGGCACGTTCCTTGG }\end{array}$ & 279-297 & 0.51 & $0.63 / 0.75$ & 62 & 3 \\
\hline
\end{tabular}

The PIC values ranged from 0.43 to 0.74 , with an average of 0.58 (Table 2). SP04, SP014 and SPO18 loci presented high PIC values, while SPO8 presented a medium PIC value. The expected heterozygosity ranged from 0.51 to 0.83 , and the observed heterozygosity values ranged from 0.63 to 0.88 (Table 2 ). The allele sizes ranged from 186 to $296 \mathrm{bp}$ among the four polymorphic transferred SSR loci (Table 2).

\section{Evaluation of $S$. tuberosa SSRs}

Among the 18 SSR loci, 12 were monomorphic and six presented polymorphism in the $6 \%$ polyacrylamide gels made with material from the eight accessions. (Table 3 ).

Table 3. Sequences of SSR primers (Forward - F, reverse - R) developed for Spondias tuberosa, alleles (bp), polymorphic information content (PIC), expected (He) and observed heterozygosity (Ho), annealing temperatures (Ta), repetition motif (MT) and number of alleles (NA).

\begin{tabular}{|c|c|c|c|c|c|c|c|}
\hline Locus & Sequence (5' - 3') & $\mathrm{T}_{\mathrm{a}}\left({ }^{\circ} \mathrm{C}\right)$ & NA & Alleles (bp) & PIC & $\mathrm{He}$ & Ho \\
\hline TUB78 & $\begin{array}{l}\text { F:TGCTCTGCCTTCCAACATGT } \\
\text { R:GTACGTGAGGGACAATGGGG }\end{array}$ & 59 & 3 & $189-218$ & 0.43 & 0.51 & 0.63 \\
\hline TUB84 & $\begin{array}{l}\text { F:CACCTCCTACGTTACTGCCA } \\
\text { R:TCAAACTGGATTCAGGCATGC }\end{array}$ & 59 & 2 & $197-208$ & 0.34 & 0.46 & 0.63 \\
\hline TUB93 & $\begin{array}{l}\text { F:AGCCTTTTTGAGTCACATGCA } \\
\text { R:ACACTGATGGTACGTGAACAA }\end{array}$ & 60 & 2 & 193-197 & 0.20 & 0.23 & 0.25 \\
\hline TUB94 & $\begin{array}{l}\text { F:TGTCTGAGGATCGAGACGAGA } \\
\text { R:GCACGCGCTTACTTATGTTGG }\end{array}$ & 60 & 3 & $234-260$ & 0.48 & 0.58 & 0.75 \\
\hline TUB98 & $\begin{array}{l}\text { F:AGCGGAAAAGAATGATGAAGGC } \\
\text { R:GTTGGCTTCTTTCTTGCGGC }\end{array}$ & 60 & 3 & $219-232$ & 0.43 & 0.51 & 0.63 \\
\hline TUB103 & $\begin{array}{l}\text { F:GGAGCAGTGAAACCCCTGAA } \\
\text { R:GTCCAGGTCGCCGTAAAGAA }\end{array}$ & 60 & 4 & $176-181$ & 0.39 & 0.44 & 0.50 \\
\hline
\end{tabular}

The allelic diversity of the $S$. tuberosa loci ranged from two to four alleles (Table $3)$; the TUB103 locus showed the greatest allelic diversity. The PICs of the evaluated $S$. 
tuberosa loci were classified as moderately informative, with the TUB93 locus presenting the smallest PIC, 0.19 (Table 3). The expected heterozygosity ranged from 0.23 to 0.575 , while the observed heterozygosity values ranged from 0.25 to 0.75 . The allele sizes ranged from 176 to $260 \mathrm{bp}$ among the six S. tuberosa SSR loci (Table 3).

\section{DISCUSSION}

The Caatinga, a seasonally dry tropical forest and woodland biome (SDTFW), has a large number of plant species, including at least 3,150 species, distributed among 950 genera and 152 families of angiosperms, of which approximately $25 \%$ are endemic to this biome, including S. tuberosa (Fernandes and Queiroz, 2018). Germplasm collection to preserve genetic variability and the pre-breeding activities of Caatinga species has been rarely done. Here, we developed and transferred new SSR loci to help guide accession collection and management of genetic resources of $S$. tuberosa, to support the development of improved cultivars. These SSR loci will aid in outcrossing rate estimation and molecular diversity investigations of germplasm collections, which are needed for genetic resource studies. For breeding programs, it is expected that the SSR loci will be useful for identifying hybrids and for mapping umbu tree agronomic characters.

Of the six new SSR loci, two were polymorphic and four were monomorphic; all of them produced repeatable amplicons in polyacrylamide gels. Of the 14 SSR loci developed by Aguilar-Bajaras et al. (2014) for $S$. radlkoferi, only four were polymorphic. Four monomorphic out of 14 SSR loci were also reported by Aguilar-Bajaras (2014) in studies of S. radlkoferi. Among the 18 umbu tree specific SSR loci (Balbino et al., 2019), only six were polymorphic in our study.

According to Balbino et al. (2019), the recent diversification of the genus Spondias (approximately 20 million years ago) may be the reason for the low degree of diversity, which would explain the high transferability success we found between $S$. radlkoferi and $S$. tuberosa. High transferability percentages, ranging from 50 to $100 \%$, for species of the same genus, have also been reported by Nazareno et al. (2011), between Butia eriospatha and B. catarinensis, by Aguilar-Bajaras et al. (2014) between S. radlkoferi and S. mombin, by Balbino et al. (2019) among $S$. tuberosa and $S$. mombin and $S$. dulcis, and by Roman et al. (2020) among Drosophila sturtevanti and species of the Drosophila saltans group.

The polymorphic information content (PIC) of the 12 SSR loci in our study ranged from 0.19 to 0.74 ; it was higher in the loci transferred from $S$. radlkoferi to $S$. tuberosa. Among the polymorphic SSR loci that we found, two loci presented slightly informative PIC values $(<0.25)$, seven were moderately informative $(0.25$ to 0.50$)$, and three were highly informative $(>0.51)$, according to the classification proposed by Bolstein et al. (1980). Araya et al. (2016) reported PICs ranging from 0.46 to 0.77 for SSR loci transferred from Passiflora edulis to another 78 wild or cultivated Passiflora species. According to Nagy et al. (2012), PIC is one most informative measures of polymorphism of a genetic marker and has become the most widely adopted for genetic studies.

The expected (He) and observed (Ho) heterozygosity among 12 SSR loci ranged from $0.22 / 0.25$ to $0.83 / 0.73$, being higher in the loci transferred from $S$. radlkoferi to $S$. tuberosa. According to Nagy et al. (2012), heterozygosity is another measure of informativeness of polymorphism of a genetic marker, and heterozygosity is widely applied in genetic studies. Balbino et al. (2019) reported He/Ho values ranging from 0.10/0.10 to 
0.64/1.0 for SSR loci among 16 individuals of $S$. tuberosa, while Aguilar-Bajaras (2014) reported $\mathrm{He} / \mathrm{Ho}$ ranging from $0.35 / 0.38$ to $0.73 / 1.0$ among 37 individuals of $S$. radlkoferi. These He / Ho values for Spondias are close to those we found in our study

Estimated allele numbers were not the same as those reported by Aguilar-Bajaras et al. (2014) and Balbino et al. (2019), because we did not use fluorescent electrophoresis and automatic estimations of amplicon size. The number of alleles observed among the 12 SSR loci ranged from 2 to 6 , which is lower than for the new SSR loci that we investigated. Aguilar-Bajaras (2014) reported allele numbers ranging from 3 to 12 among 37 individuals of $S$. radlkoferi, while Balbino et al. (2019) reported allele numbers ranging from 2 to 5 among 16 individuals of $S$. tuberosa, with the highest frequency $(45 \%)$ of loci with two alleles. The allele numbers in our study are close to those observed for $S$. tuberosa and lower than what was observed for $S$. radlkoferi.

Of the 38 SSR loci evaluated in our study, 12 were polymorphic, with 2 to 12 alleles; 10 had moderately informative PICs. Nine SSR loci with $\mathrm{He} / \mathrm{Ho}>0.50$ could be indicated for population studies, germplasm collection and management, and to aid in the development of new umbu tree cultivars. The low frequency of polymorphic SSRs (31.6\%) can be attributed to the small sample size.

\section{CONCLUSIONS}

Among the 38 loci that were evaluated $S$. tuberosa, 12 were polymorphic in the genotyped sample, including two new loci for this species. The six new SSR loci and the 14 SSR loci transferred from $S$. radlkoferi increase the number of available loci to 38 for population studies, germplasm collection administration, and breeding programs for the development of improved umbu tree cultivars.

\section{ACKNOWLEDGMENTS}

The authors thank the Coordination for the Improvement of Higher Education Personnel for granting the scholarship to VN Santos. CAF Santos had a research productivity grant from the Brazilian National Council for Scientific and Technological Development.

\section{CONFLICTS OF INTEREST}

The authors declare no conflict of interest.

\section{REFERENCES}

Almeida CC, PCLC and Guerra M (2007). Karyotype differentiation among Spondias species and the putative hybrid Umbu-cajá (Anacardiaceae). Bot. J. Linn. Soc. 155: 541-547. Doi: 10.1111/j.1095-8339.2007.00721.x.

Aguilar-Barajas E, Sork VL, González-Zamora A, Rocha-Ramírez V, et al. (2014). Isolation and characterization of polymorphic microsatellite loci in Spondias radlkoferi (Anacardiaceae). Appl. Plant Sci. 2(11): 1400079. Doi: 10.3732/apps.1400079.

Balbino E, Martins G, Morais S and Almeida C (2019). Genome survey and development of 18 microsatellite markers to assess genetic diversity in Spondias tuberosa Arruda Câmara (Anacardiaceae) and cross-amplification in congeneric species. Mol. Biol. Rep. 46: 3511-3517. Doi: 10.1007/s11033-019-04768-w.

Bolstein D, White RL, Skolnick M and Davis RW (1980). Construction of genetic linkage map in man using restriction fragment length polymorphism. Am. J. Hum. Genet. 32: 314-331. 
Fernandes MF and Queiroz LP (2018). Vegetação e flora da Caatinga. Cienc. Cult. 70: 51-56. Doi: 10.21800/231766602018000400014.

IBGE (2020). Produção da extração vegetal e silvicultura. Available at [https://sidra.ibge.gov.br/tabela/289\#resultado] . Accessed 29 October 2020.

Lima Filho JMP and Santos CAF (2009). Avaliações fenotípicas e fisiológicas de espécies de Spondias tendo como porta enxerto o umbuzeiro (Spondias tuberosa Cam.). Caatinga. 22: 59-63.

Lima MAC, Silva SM and Oliveira VR (2018). Umbu - Spondias tuberosa. In: Exotic Fruits (Rodrigues S, Silva EO, eds). Academic Press, pp. 427-433. Doi:10.1016/B978-0-12-803138-4.00057-5.

Marshall TC, Slate J, Kruuk L and Pemberton JM (1998). Statistical confidence for likelihood based paternity inference in natural populations. Molec. Ecol. 7 (5): 639-655, 1998. Doi: 10.1046/j.1365-294x.1998.00374.x.

Nascimento AS, Alves RM, Silva CRS, Albuquerque PSB, et al. (2019). Transferibilidade e mapeamento de microssatélites entre Theobroma cacao L. e Theobroma grandiflorum (WILLD. EX. SPRENG.) Schum. AgroTropica. 31: 85-102. Doi: 10.21757/0103-3816.2019v31n2p85-102.

Nagy S, Poczai P, Cernak I, Gorji AM, et al. (2012) PICcalc: an online program to calculate polymorphic information content for molecular genetic studies. Biochem. Genet. 50: 670-672. Doi: 10.1007/s10528-012-9509-1.

Nazareno AG, Zucchi MI and Reis MS (2011). Microsatellite markers for Butia eriospatha (Arecaceae), a vulnerable palm species from the Atlantic Rainforest of Brazil. Am. J. Bot. 98: 198-200. Doi: 10.3732/ajb.1100064. Epub 2011 Jun 23.

Nogueira AM, Ferreira A and Ferreira MFS (2015). Transferability of Microsatellites from Psidium guajava to Eugenia, Myrciaria, Campomanesia and Syzygium Species (Myrtaceae). Plant Mol. Biol. Rep. 34: 249-256. Doi: 10.1007/s11105-015-0921-7.

Prado DE and Gibbs PE (1993). Patterns of species distribution in the dry season forests of South America. Ann. Mo. Bot. Gard. 80: 902-927. Doi: 10.2307/2399937.

Oliveira EJ, Pádua JG, Zucchi MI, Vencovsky R, et al. (2006). Origin, evolution and genome distribution of microsatellites. Genet. Mol. Biol. 29: 294-307. Doi: 10.1590/S1415-47572006000200018.

Romam BE, Trava BM and Madi-Ravazzi L (2020). Development and transferability of microsatellite markers for species of the saltans group of Drosophila (Diptera: Drosophilidae). Genet. Mol. Res. 19(4): GMR18700. Doi: $10.4238 / \mathrm{gmr} 18700$.

Santos CAF, Nascimento CS and Campos CO (1999). Preservação da variabilidade genética e melhoramento do umbuzeiro. Rev. Bras. Frutic. 21: 104-109.

Santos CAF and Gama RNCS (2013). An AFLP estimation of the outcrossing rate of Spondias tuberosa (Anacardiaceae), an endemic species to the Brazilian semiarid region. Int. J. Trop. Biol. Conserv. 61: 577-582. Doi:10.15517/RBT.V61I2.11150.

Varshney RK, Graner A, and Sorrells ME (2005). Genic microsatellite markers in plants: features and applications. Trends Biotechnol. 23: 48-55. Doi: 10.1016/j.tibtech.2004.11.005.

Zeraik ML, Queiroz EF, Marcourt L, Ciclet O, et al. (2016). Antioxidants, quinone reductase inducers and acetylcholinesterase inhibitors from Spondias tuberosa fruits. J. Funct. Food 21: 396-405. Doi: 10.1016/j.jff.2015.12.009. 